\title{
PENGELOLAAN OBLIGASI SYARIAH (SUKUK) PADA DANA HAJI INDONESIA
}

\author{
Feri Irawan \\ STAI Nahdlatul Wathan Samawa Sumbawa Besar-NTB \\ feri.irawan@stainwsamawa.ac.id
}

\begin{abstract}
Abstrak: Dewasa ini perkembangan keuangan syariah semakin berkembang pesat. khususnya pada surat berharga syariah. Untuk surat berharga syariah sendiri telah mengalami perkembangan yang diawali dengan penerbitan Surat Berharga Syariah Negara atau biasa disebut sukuk pada tahun 2000. Sukuk yang telah diterbitkan diantaranya adalah Sukuk Ritel. Menginjak tahun 2009, pemerintah kembali melakukan diversivikasi pada sukuk dengan menerbitkan Sukuk Dana Haji Indonesia. Penerbitan Sukuk Dana Haji Indonesia didasari oleh semangat antara Kementrian Agama Republik Indonesia sebagai pemegang keuangan dana Haji dan Kementrian Keuangan sebagai pengelola sukuk. Hingga tahun 2019 sudah terdapat tujuh seri Sukuk Dana Haji Indonesia yang diterbitkan dan tiga diantaranya sudah jatuh tempo. Dalam prakteknya, Sukuk Dana Haji Indonesia menggunakan akad Ijarah Al-khadamat, metode private placement, dan imbal hasil fix coupon yang akan dibayarkan setiap bulannya. Dalam penelitian ini, menggunakan metode
\end{abstract}


deskriptif kualitatif untuk mengetahui kelebihan dan kekuarangan Sukuk Dana Haji Indonesia serta deskriptif kuantitatif untuk mengatahui pengelolaan dana haji pada Sukuk Dana Haji Indonesia yang dilihat dari pengelolaan anggaran negara. Penelitian ini menyimpulkan bahwa penempatan dana haji pada Sukuk Dana Haji Indonesia menguntungkan bagi Kementrian Agama karena bebas default Risk. Sedangkan dari sisi Kementrian Keuangan akan menambah investor baru dalam pengelolaan anggaran negara. Kata Kunci: Obligasi Syariah (Sukuk), Dana Haji Indonesia

\section{Pendahuluan}

Indonesia merupakan negara dengan jumlah penduduk muslim terbesar pertama di dunia. Kaitannya dengan hal tersebut, kuota haji Indonesia merupakan kuota terbesar di dunia. Calon haji Indonesia telah mencapai lebih dari 700.000, sementara kuota haji hanya 207.000. Sampai dengan 21 April 2019 saja jumlah calon jamaah haji yang mendaftar sebanyak 781.595 orang, terdiri dari calon jamaah haji reguler sebanyak 761.865 orang dan calon jamaah haji khusus sebanyak 19.730 orang. ${ }^{1}$

Melihat jumlah calon jamaah haji dibandingkan dengan kuota yang tersedia, tentunya seorang calon haji dalam suasana normal harus menunggu sekitar tiga tahun atau lebih. Apabila calon jamaah haji telah membayar down payment sebesar Rp 20 juta atau 3000 USD, maka uang tersebut akan mengendap selama beberapa waktu. Dengan demikian jumlah dana yang terkumpul di Departemen Agama sebesar Rp 15,273 triliun dan US \$59,19 akan semakin besar seiring bertambahnya pendaftar haji setiap harinya. Dana tersebut akan mengendap. Dalam persepsi pengelolaan keuangan, nilai uang akan tergerus oleh inflasi sehingga mengalami penurunan.

Hal ini memberikan suatu gambaran mengenai potensi pengelolaan keuangan yang apabila dilakukan dengan tetap berprinsip pada rambu-rambu kehati-hatian dapat dilakukan dengan tanpa menghilangkan aspek untuk dapat memaksimalkan nilai uang. ${ }^{2}$

Selama ini pengelolaan dana haji dilakukan oleh Departemen Agama. Dana-dana haji yang ada pada Departemen Agama ditempatkan di deposito perbankan. Dana-dana tersebut hanya dijamin Rp 2 miliar oleh

\footnotetext{
1 Penempatan Dana Haji dan Dana Abadi Umat ke SBSN Lebih Aman", artikel diakses pada 28 januari 2010 dari http://www.jurnalhaji.com.htm.

2 "Sambutan Menteri Keuangan pada Acara Penandatanganan MoU antara Menteri Keuangan dan Menteri Agama dalam rangka Penempatan Dana Haji dan DAU dalam SBSN", artikel diakses pada 1 Februari 2019 dari http://www.depkeu.go.id.htm.
} 
LPS. Bila kita bandingkan dengan akumulasi dana haji per individu dan jumlah calon haji, angka Rp 2 miliar tentu sangat kecil sekali. Dan akan sangat disayangkan apabila jumlah dana haji yang mengendap cukup besar tanpa diputar di sektor yang produktif.

Maka dari itu dana penyelenggaraan haji yang tersebar di 21 Bank di Indonesia secara bertahap akan ditarik oleh Departemen Agama. Dana ini dialihkan dalam bentuk investasi sukuk negara (SBSN) dengan seri SDHI 2019. ${ }^{3}$

Kaitannya dengan hal tersebut, Departemen Keuangan dalam kapasitas sebagai pengelola keuangan negara melihat bahwa negara membutuhkan suatu pembiayaan yang sedemikian sehingga instrumen yang dikeluarkan oleh pemerintah memiliki risiko terkecil, keamanan tertinggi, beban yang serendah-rendahnya kepada negara.

Oleh karena itu instrumen sukuk menjadi salah satu prioritas. Dana Haji atau Dana Abadi Umat merupakan salah satu potensi yang dapat digunakan untuk membiayai anggaran negara yang memberikan keuntungan dan manfaat yang sama bagi kedua belah pihak. ${ }^{4}$ Dari sini muncullah beberapa pertanyaan seperti: 1) Bagaimana pengelolaan dana haji pada Sukuk Dana Haji Indonesia (SDHI) ditinjau dari perspektif pengelolaan anggaran negara?. 2) Bagaimana dampak pengelolaan Sukuk Dana Haji Indonesia terhadap pengelolaan anggaran ditinjau dari sisi Kementrian Agama dan Kementrian Keuangan?.

\section{Investasi Pada Obligasi Syariah (Sukuk)}

Menurut Nurul Huda, Obligasi adalah surat utang yang dikeluarkan oleh emiten (dapat berupa badan hukum/perusahaan atau pemerintah) yang memerlukan dana untuk kebutuhan operasi maupun ekspansi mereka. Investasi pada obligasi memiliki potensial keuntungan lebih besar daripada produk perbankan. ${ }^{5}$

Obligasi merupakan instrumen utang jangka panjang, yang pada umumnya diterbitkan dalam jangka berkisar antara lima sampai sepuluh tahun lamanya. Ada juga yang jatuh tempo selama satu tahun. Semakin pendek jangka waktu obligasi, maka semakin diminati oleh investor karena dianggap resikonya kecil. Pada saat jatuh tempo, pihak penerbit obligasi berkewajiban untuk melunasi pokok investasi di dalam obligasi tersebut. ${ }^{6}$

3 Umi Kalsum dan Agus Dwi Darmawan, "Depag Siap Tarik Dana Haji di 21 Bank”, artikel diakses pada 1 Februari 2019 dari http:/ /www.bisnis.vivanews.com 2.htm.

${ }_{4}^{4}$ Diakses dari http://www.depkeu.go.id.htm, pada tanggal 1 Februari 2019

5 Nurul Huda dan Mustafa E. Nasution, Investasi pada Pasar Modal Syariah, h. 12

6 Abdul Manan, Obligasi Syariah, artikel diakses pada 9 Juli 2019 dari http://www.badilag.net 
Obligasi jangka panjang merupakan investasi lebih beresiko dibanding investasi dalam surat utang pemerintah jangka pendek dan bahwa investasi saham jauh lebih beresiko.

\section{Pengertian Obligasi Syariah (Sukuk)}

Secara terminologi shak (sukuk) adalah sebuah kertas (buku) atau catatan yang padanya terdapat perintah dari seseorang untuk pembayaran uang dengan jumlah tertentu pada orang lain yang namanya tertera pada kertas tersebut. Kata sukuk juga berasal dari bahasa Persia yaitu 'jak', lalu masuk dalam bahasa Arab dengan nama 'shak'. Shak adalah asal kata dari kata cek atau cheque yang terdapat dalam bahasa Inggris dimana ia pada dasarnya adalah surat hutang. ${ }^{8}$

Sukuk dapat pula diartikan dengan Efek Syariah berupa sertifikat atau bukti kepemilikan yang bernilai sama dan mewakili bagian penyertaan yang tidak terpisahkan atau tidak terbagi atas kepemilikan aset berwujud tertentu, nilai manfaat dan jasa atas aset proyek tertentu atau aktivitas investasi tertentu, kepemilikan atas aset proyek tertentu atau aktivitas investasi tertentu.

\section{Landasan Hukum Obligasi Syariah}

Obligasi Syariah dijelaskan dalam QS Al-Maidah ayat 1 dan Al-Isra' ayat 34 .

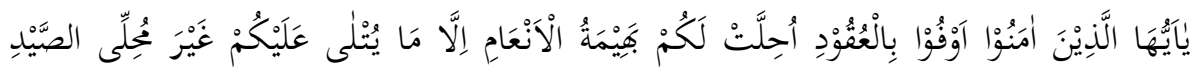

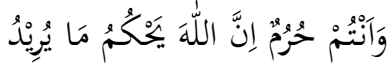

Artinya: "Hai orang-orang yang beriman! Penubilab aqad-aqad itu. Hewan ternak dihalalkan bagimu, kecuali yang akan disebutkan kepadamu, dengan tidak menghalalkan berburu ketika kamu sedang beribram (baji atau umrah). Sesunggubnya Allab menetapkann bukum sesuai dengan yang dia kehendaki”.

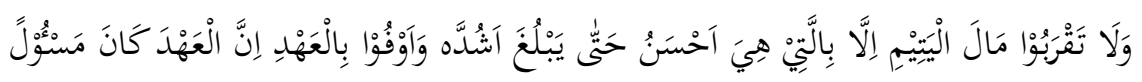

"Dan janganlah kamu mendekati harta anak yatim, kecuali dengan cara yang lebih baik (bermanfaat) sampapi ia dewasa dan penubilah janji, sesunggubnya janji itu pasti diminta pertanggungjawabannya”.

\section{Metodologi Penelitian}

Penelitian ini termasuk kedalam penelitian deskriptif. Metode

\footnotetext{
7 Bodie, Kane dkk., Invesments (Investasi), Jakarta: Salemba 4, 2006, hal. 216.

8 Abdul Hamid, Pasar Modal Syariah (Jakarta: Lembaga Penelitian UIN, 2009), h.68
} 
deskriptif adalah penelitian yang bermaksud untuk membuat pencandraan (gambaran) mengenai situasi-situasi atau kejadian dalam pengertian ini penelitian deskriptif menggunakan data dasar deskriptif semata, tidak perlu mencari atau menerangkan saling berhubungan, menguji hipotesis, membuat ramalan, atau mendapatkan makna dan implikasi. Pendapat lainnya mengatakan bahwa metode deskriptif bertujuan untuk menggambarkan sifat sesuatu yang tengah berlangsung pada saat riset dilakukan dan memeriksa sebab-sebab dari gejala tertentu. ${ }^{9}$

Disebut juga dengan penelitian survei deskriptif (penelitian pengembangan), yaitu penelitian yang bertujuan untuk mengembangkan teori dari masalah-masalah suatu fenomena yang dihubungkan dengan teori-teori dari suatu ilmu tertentu untuk memecahkan masalah secara rasional. ${ }^{10}$

Penelitian berupa penelitian langsung dengan cara survei pada Kementrian Keuangan. Penelitian ini juga menggunakan pendekatan dokumen yaitu melakukan pengumpulan data dan informasi melalui arsip, dokumen, serta laporan yang dipublikasikan oleh Kementrian Keuangan.

Sedangkan Jenis datanya meliputi: Data primer: hasil wawancara dan observasi langsung mengenai Sukuk Dana Haji Indonesia. Data sekunder: berupa bahan acuan lainnya yang berisikan informasi tentang Sukuk Dana Haji Indonesia (SDHI) berupa data, buku, tulisan, jurnal, majalah, dan lain-lain.

Untuk memperoleh suatu kebenaran ilmiah dalam penulisan skripsi maka penulis menggunakan metode pengumpulan dengan cara Studi Kepustakaan (mempelajari dan menganalisis secara sistematis buku-buku, surat kabar, makalah ilmiah, peraturan perundang-undangan dengan materi yang dibahas dalam skripsi ini) dan juga Wawancara yang dilakukan untuk mengetahui lebih mendalam tentang penempatan dana haji pada Sukuk Dana Haji Indonesia dari pihak yang bersangkutan.

Untuk menganalisa efektifitas pengelolaan Sukuk Dana Haji Indonesia digunakan dua pendekatan analisa, yaitu: Analisis Kuantitatif

Analisa kuantitatif digunakan untuk melihat pengelolaan sukuk dana pada pengeloalaan anggaran negara. Analisa kuantitatif ini berdasarkan data keuangan yaitu outstanding SBSN dan data keuangan lain yang telah dipublikasikan oleh Kementrian Keuangan. Analisis Kualitatif

Analisa kualitatif digunakan untuk mengetahui kekurangan dan kelebihan pengelolaan dana haji pada Sukuk Dana Haji Indonesia. Analisa

\footnotetext{
9 Sumadi Suryabrata, Metodologi Penelitian (Jakarta: Rajawali Press, 2002), h. 18.

10 Etty Rochaety, dkk., Metode Penelitian Bisnis, Jakarta: Mitra Wacana Media, 2007, h. 13.
} 
kualitatif ini berdasarkan hasil wawancara formal secara terstruktur ke Kementrian Keuangan dan data-data berupa artikel, berita, dan lainnya yang dapat memberikan gambaran.

\section{PEMBAHASAN}

\section{Pengelolaan Sukuk Dana Haji Dilihat dari Pengelolaan Anggaran Negara}

1. Pengelolaan Biaya Penyelenggaraan Haji

Setiap warga Indonesia yang hendak menunaikan ibadah haji wajib menyetorkan Biaya Penyelenggaraan Ibadah Haji (BPIH). BPIH tersebut disetorkan melalui Bank Penerima Setoran (BPS) ke rekening Menteri Agama. Untuk selanjutnya BPIH tersebut dikelola dengan mempertimbangkan nilai manfaat yang didapat untuk membiayai belanja operasional penyelenggaraan ibadah haji.

Dalam rangka pembenahan penyelenggaraan ibadah haji maka pengelolaan keuangan haji diarahkan lebih akuntabel dan transparan. Untuk itu Kementrian Agama memutuskan menempatkan dana haji pada Sukuk Dana Haji Indonesia bekerjasama dengan Kementerian Keuangan.

\section{Sukuk Dana Haji Indonesia}

Penempatan dana haji pada Surat Berharga Syariah Negara, termasuk ke dalam Surat Berharga Syariah Negara jangka panjang dengan imbal hasil tetap atau disebut dengan fix coupon.

Adapun Kementrian Keuangan menerbitkan Sukuk Dana Haji itu sendiri yaitu dalam rangka pengembangan pasar syariah. Mengingat SBSN atau sukuk merupakan salah satu instrumen yang digunakan oleh pemerintah dengan maksud untuk memperluas sumber penerimaan Anggaran Pendapatan dan Belanja Negara (APBN).

Maka dengan diterbitkannya Sukuk Dana Haji Indonesia akan menambah outstanding atau jumlah penerbitan Surat Berharga Syariah Negara, dimana secara tidak langsung akan menambah penerimaan APBN.

Gambar 4.1 Tabel Realisasi Penerbitan SBN 2019

\begin{tabular}{|l|c|c|c|}
\hline $\begin{array}{l}\text { SBN Jatuh } \\
\text { Tempo 2019 }\end{array}$ & $\begin{array}{c}\text { Target } \\
\text { APBN-P }\end{array}$ & Realisasi & \% Realisasi \\
\cline { 2 - 4 } & 67.540 .415 & 57.581 .768 & $85,26 \%$ \\
\hline $\begin{array}{l}\text { SBN Netto } \\
\text { (APBN) }\end{array}$ & 107.500 .400 & 87.580 .092 & $81,47 \%$ \\
\hline Rencana Buyback & 3.000 .000 & 168.000 & $5,60 \%$ \\
\hline $\begin{array}{l}\text { Kebutuhan } \\
\text { penerbitan 2019 }\end{array}$ & 178.040 .815 & 145.329 .860 & $81,63 \%$ \\
\hline SUN & & 120.745 .000 & $82,12 \%$ \\
\hline
\end{tabular}




\begin{tabular}{|l|c|c|c|}
\hline SUN Domestik & & 102.195 .000 & \\
\hline SUN Valas & & 18.550 .000 & \\
\hline SBSN & & 25.584 .860 & $87,80 \%$ \\
\hline IFR & & 5.768 .000 & \\
\hline SBSN Ritel & & 8.033 .860 & \\
\hline SDHI & & 10.783 .000 & \\
\hline SBSN Valas & & - & \\
\hline
\end{tabular}

Sumber: Buku Perkembangan Utang Negara edisi Oktober 2019

Dari tabel di atas, dapat dijelaskan bahwa realisasi penerbitan Surat Berharga Negara adalah sebesar 57,5 triliun rupiah dan Surat Berharga Syariah Negara sebesar 24,5 Triliun. Dari total SBSN tersebut, realisasi penerbitan Sukuk Dana Haji Indonesia sebesar 10,7 triliun rupiah. Jumlah tersebut cukup besar mengingat Sukuk Dana Haji Indonesia pertamakali diterbitkan tahun 2009.

Nilai kupon SDHI tercatat antara 7,55-8,52 \% dengan tenor dua belas bulan bulan sampai dengan tiga tahun yang disesuaikan dengan kebutuhan Kementerian Agama.

Sampai saat ini memiliki jumlah imbalan yang sudah dibayarkan sebelum pajak sekitar Rp 252,3 miliar. Dengan potongan pajak sebesar Rp 47,1 miliar, maka neto hasil investasi yang diperoleh adalah Rp 205,2 miliar. $^{11}$

Dari total Sukuk Dana Haji yang diterbitkan, sudah ada 3 jenis yang jatuh tempo. Dari ketiga jenis tersebut, diperoleh hasil perhitungan kupon sebagai berikut:

Gambar 4.2 Tabel Sukuk Dana Haji Jatuh Tempo

\begin{tabular}{|c|c|c|c|l|l|l|}
\hline No & \multicolumn{1}{|c|}{ Seri } & $\begin{array}{c}\text { Tgl } \\
\text { Terbit }\end{array}$ & $\begin{array}{c}\text { Tgl Jatuh } \\
\text { Tempo }\end{array}$ & $\begin{array}{c}\text { Tg1 Bayar } \\
\text { Kupon }\end{array}$ & Kupon & $\begin{array}{c}\text { Nominal } \\
\text { Sukuk }\end{array}$ \\
\hline 1 & $\begin{array}{l}\text { SDHI } \\
2019 \text { A }\end{array}$ & $07-$ Mei-18 & 07-Mei-19 & $\begin{array}{l}\text { Tgl } \\
7 / \text { bulan }\end{array}$ & $8,52 \%$ & Rp1,5 T \\
\hline 2 & $\begin{array}{l}\text { SDHI } \\
2019 \text { B }\end{array}$ & $24-J u n-18$ & $07-M e i-19$ & $\begin{array}{l}\text { Tgl } \\
7 / \text { bulan }\end{array}$ & $7,38 \%$ & Rp $850 \mathrm{M}$ \\
\hline 3 & $\begin{array}{l}\text { SDHI } \\
\text { 2019 C }\end{array}$ & 24-Jul-18 & 24-Aug-19 & $\begin{array}{l}\text { Tgl } \\
24 / \text { bulan }\end{array}$ & $7,89 \%$ & Rp 336 M \\
\hline
\end{tabular}

Sumber: Outstanding SBN, http:// wmw.dmo.or.id

Perhitungan jumlah kupon yang diterima dengan pengurangan pajak sebesar $15 \%$

11 Rahmat Waluyanto, Pemerintah Kembali Terbitkan Sukuk, artikel diakses pada 17 Mei 2019 dari http:/ / republika.co.id 
Gambar 4.3 Tabel Sukuk Dana Haji Jatuh Tempo

\begin{tabular}{|c|l|l|}
\hline No & \multicolumn{1}{|c|}{ Seri } & \multicolumn{1}{c|}{ Nominal Kupon } \\
\hline 1 & SDHI 2019 A & Rp 90.545 .000 .000 \\
\hline 2 & SDHI 2019 B & $\operatorname{Rp~471.431.000.00~}$ \\
\hline 3 & SDHI 2019 C & $R p 1.877 .820 .000$ \\
\hline
\end{tabular}

Sumber: data diolah pribadi

\section{Kebijakan Pengelolaan Anggaran Negara}

Kebijakan defisit anggaran akan ditempuh oleh pemerintah jika ternyata belanja atau pengeluaran pemerintah lebih besar dibandingkan dengan pendapatan yang diterima setelah puluhan tahun pemerintah Indonesia enggan mengakui adanya defisit anggaran dan selalu mengatakannya sebagai anggaran berimbang, akhirnya pada tahun 2000 defisit anggaran diakui secara eksplisit. ${ }^{12}$

Berdasarkan data Dirjen Pengelolaan Hutang, dalam APBN-P 2019 defisit anggaran mencapai 2,1\% terhadap GDP atau sekitar Rp 133,7 T dengan GDP Rp 5.393,77 T (2009). Sementara rasio total utang terhadap GDP nominal asumsi APBN-P 2019 mencapai 26\%. ${ }^{13}$

Bisa dikatakan selama periode 1997 hingga 2009, tepatnya hingga sekarang. Pemerintah hampir selalu mengandalkan utang dalam negeri berupa penerbitan surat-surat berharga atau obligasi pemerintah. Penerimaan pembiayaan memang lebih banyak didominasi oleh surat berharga dibandingkan dengan pinjaman luar negeri serta dalam negeri dan sumber non utang lainnya.

Hal tersebut selaras dengan kebijakan yang diambil pemerintah bahwa lebih memprioritaskan SBN dibanding utang luar negeri dan dalam negeri dengan alasan membantu pemerintah agar tidak terlalu ketergantungan dengan utang itu sendiri.

Selain itu pinjaman luar negeri juga hanya dibatasi untuk pinjaman lunak pembangunan infrastruktur dan energi, perubahan iklim, dan proyek pembangunan lainnya seperti kesehatan dan pendidikan. ${ }^{14}$

Dalam buku Laporan Pertanggungjawaban Pengelolaan Surat Berharga Negara tahun 2009, disebutkan bahwa kebijakan penerbitan

\footnotetext{
12 Adiwarman A. Karim, Ekonomi Makro Islami ( Jakarta: PT RajaGrafindo Persada, 2007), h. 241.

13 Dimas Bagus W.K., Telaah Kritis Budaya Berbutang Indonesia, diakses pada 23 Oktober 2019

dari http:/ / suarapembaca.detik.com/read/2019/07/07/181558/1395067/471/telaah-kritisbudaya-berhutang-indonesia

14 Pengelolaan Utang Pemerintah RI, diakses pada tanggal 22 November 2019 dari http://www.dmo.or.id/dmodata/6Publikasi/4Presentasi/Presentasi_diskusi)dirjenPU_ dengan_forkem_19April2019.pdf
} 
SBSN dilakukan dalam rangka perluasan basis investor, diversifikasi sumber pembiayaan, dan pengembangan pasar keuangan dalam negeri, instrumen keuangan ini pada prinsipnya sama seperti surat berharga konvensional, dengan perbedaan pokok antara lain berupa penggunaan konsep imbalan dan bagi hasil sebagai pengganti bunga, adanya suatu transaksi pendukung (underlying transaction) berupa sejumlah tertentu aset yang menjadi dasar penerbitan sukuk, serta adanya aqad atau penjanjian antara para pihak berdasarkan prinsip-prinsip syariah.

Kaitannya dengan hal tersebut, dalam kebijakan Pengelolaan Utang tahun 2018-2019 disebutkan pula bahwa tujuan pengelolaan utang salah satunya adalah diversivikasi sumber pembiayaan termasuk pengembangan instrumen pembiayaan syariah. ${ }^{15}$

Berikut ini adalah tabel mengenai gambaran hutang negara dari tahun 2007 hingga tahun 2019.

\section{Gambar 4.4 Gambaran Utang Negara}

\begin{tabular}{|c|c|c|c|c|}
\hline Tahun & \multicolumn{2}{|c|}{ Pinjaman } & \multicolumn{2}{c|}{ Surat Berharga Negara } \\
\hline 2007 & 453 & $82 \%$ & 100 & $18 \%$ \\
\hline 2008 & 438 & $47 \%$ & 502 & $53 \%$ \\
\hline 2009 & 583 & $47 \%$ & 652 & $53 \%$ \\
\hline 2010 & 613 & $48 \%$ & 611 & $52 \%$ \\
\hline 2011 & 570 & $47 \%$ & 655 & $53 \%$ \\
\hline 2012 & 583 & $47 \%$ & 649 & $53 \%$ \\
\hline 2013 & 637 & $49 \%$ & 662 & $51 \%$ \\
\hline 2014 & 620 & $47 \%$ & 693 & $53 \%$ \\
\hline 2015 & 559 & $43 \%$ & 743 & $57 \%$ \\
\hline 2016 & 586 & $42 \%$ & 803 & $58 \%$ \\
\hline 2017 & 730 & $45 \%$ & 906 & $55 \%$ \\
\hline 2018 & 611 & $38 \%$ & 379 & $62 \%$ \\
\hline 2019 & 594 & $36 \%$ & 1059 & $64 \%$ \\
\hline
\end{tabular}

Sumber: Buku Saku Perkembangan Utang Negara (Oktober 2019)

Dari tabel di atas terlihat bahwa memang hutang pemerintah hingga tahun 2019 yang berasal dari penerbitan surat berharga negara lebih tinggi, yaitu sebesar $64 \%$ dibandingkan dengan hutang dari pinjaman luar negeri yang sebesar $36 \%$. Serta dapat dilihat pula bahwa dari tahun ke tahun perkembangan utang negara melalui Surat Berharga Negara mengalami kenaikan.

Untuk menutup defisit anggaran, pemerintah membuka opsi

15 Agus P. Laksono, Sukuk Negara (SBSN) Instrumen Pembiayaan dan Investasi Berbasis Syariah, disampaikan pada Materi Sukuk Goes to Campus, Jakarta 7 Mei 2019 
pendanaan melalui beberapa sumber, yaitu: ${ }^{16}$

1. Pinjaman luar negeri dengan persyaratan lunak dan jangka panjang.

2. Membuka akses sumber pembiayaan di pasar internasional seperti obligasi global dan sukuk global.

3. Mengutamakan penerbitan Surat Berharga Negara (SBN) Rupiah di pasar dalam negeri. Instrumen pembiayaan dalam negeri yang digunakan pemerintah Indonesia adalah Surat Berharga Negara yang terdiri dari Surat Utang Negara (berupa Surat Perbendaharaan Negara (SPN/T-Bills) dan Obligasi Negara (ORI, FR/VR Bond, Global Bond) dan Surat Berharga Syariah Negara (SBSN) /Sukuk Negara baik SBSN berjangka pendek (Islamic T-Bills) maupun jangka panjang (Ijarah Fixed Rate, Global Sukuk, Sukuk Dana Haji Indonesia).

Jenis-jenis instumen tersebut, oleh pemerintah dikategorikan sebagai instrumen utang. Dimana penggunaan atau pengelolaan pada masing-masing instrumen tersebut berbeda. Untuk penyalurannya, dikategorikan menjadi lima, yaitu untuk pengelolaan kas negara, untuk pembiayaan defisit negara, pembiayaan kegiatan negara, pengelolaan portofolio dan pembiayaan-pembiyaan lain.

Pemerintah memiliki beberapa jenis instrumen pembiayaan negara. Dalam bentuk jenis instrumen pinjaman yang dimasukan ke dalam jenis instrumen utang pemerintah, baik pinjaman dalam negeri maupun pinjaman luar negeri. Begitupula dengan Surat Berharga Negara, SUN maupun Sukuk Negara. Dalam upaya pengelolaan utang dengan baik, maka pemerintah lebih memprioritaskan penerbitan Surat Berharharga Negara karena lebih bisa dikembangkan untuk pasar keuangan pemerintah. Mengenai pos-pos penyaluran atau penggunaan jenis instrumen utang negara tersebut,

Dana haji yang masuk ke dalam kas negara akan dikelola oleh bagian perbendaharaan negara. Dalam pengelolaan dan penggunaan Sukuk dana haji di anggaran negara, tidak ada prioritas ataupun penempatan khusus untuk pos tertentu. Penggunaan dana-dana tersebut termasuk ke dalam general financing, yaitu penggunaan dana untuk pembiayaan yang bersifat umum bukan untuk project financing, yaitu pembiayaan untuk jenis pembangunan proyek tertentu. ${ }^{17}$

Sukuk Dana Haji Indonesia termasuk ke dalam SBSN jangka panjang, dimana penggunaan SBSN jangka panjang adalah untuk

16 Kritik Ekonomi Islam terhadap APBN", Majalah Sharing edisi 35 tahun IV (November 2009): h.11.

17 Agus P. Laksono, Staff Direktorat Pembiayaan Syariah-Direktorat Jenderal Pengelolaan Utang Kementrian Keuangan, Wawancara Pribadi, Jakarta, 18 Oktober 2019 
pembiayaan kegiatan dan pembiayaan defisit. Serta melihat pos penggunaan Sukuk Dana Haji Indonesia adalah untuk generalfinancing dapat dikatakan bahwa Sukuk Dana Haji memang digunakan untuk pembiayaan defisit. Bukan untuk pembangunan proyek tertentu.

\section{Kelebihan dan Kekurangan Sukuk Dana Haji Indonesia}

Dapat dikatakan bahwa Sukuk Dana Haji Indonesia sebagai salah satu instrumen pembiayaan negara memiliki beberapa kelabihan dibandingkan dengan dana haji yang diletakan di deposito perbankan, yaitu:

1. Memberikan imbalan tetap (fix return), yaitu imbalan diberikan secara periodik. Imbal balik yang diberikan oleh Sukuk Dana Haji Indonesia adalah fixed coupon yang disepakat di awal akad (predetermined) dan dibayarkan secara periodik setiap bulannya.

2. Investasi yang aman, yaitu pembayaran imbalan dan nilai nominal dijamin oleh negara dalam Undang-Undang No.19 Tahun 2008 dan Undang-Undang APBN setiap tahunnya.

3. Pajak terhadap imbalan SBSN (15\%) lebih kecil daripada pajak terhadap bagi hasil deposito (20\%).

Pada dasarnya sukuk dana haji indonesia disemangati oleh kedua belah pihak, yaitu kepentingan Kementrian Agama dan Kementrian Keuangan. ${ }^{18}$ Kelebihan yang didapat dari penempatan dana haji ke sukuk dana haji indonesia dari sisi Kementrian Agama diantaranya yaitu:

1. Menghindari sistem risk perbankan

Sebelum ditempatkan pada sukuk dana haji Indonesia, dana haji ditempatkan di deposito perbankan. Dari sekian triliun dana haji yang masuk ke perbankan, hanya senilai 2 miliar. Sekiranya perbankan mengalami collaps maka uang dana haji senilai sekian triliun tidak ada yang menjamin.

Untuk alasan-alasan yang kuat, pinjaman pemerintah jauh lebih aman dan dapat dipertanggung jawabakan daripada didepositokan di bank. Pemerintah lebih dapat dipercaya dan janjinya lebih dapat diyakini daripada bank karena peminjam mempunyai jaminan dari pemerintah akan kembalinya uang pinjaman itu tepat pada waktu yang telah dijanjikan.

Dan diantara beberapa orang, dengan kondisi semacam itu lebih senang pada pinjamn pemerintah daripada pada bank lain sebagai tujuan utama mereka menyimpan uang. Di samping itu

18 Agus P. Laksono, Staff Direktorat Pembiayaan Syariah-Direktorat Jenderal Pengelolaan Utang Kementrian keuangan RI, Wawancara Pribadi, Jakarta, 18 Oktober 2019 
tindakan semacam ini merupakan perbutan amal, Karena mereka akan membantu pemerintah demi kebaikan seluruh masyarakat. ${ }^{19}$

2. Lebih terjamin dari sisi kesyariahannya

Dengan ditempatkannya dana haji pada sukuk dana haji Indonesia akan lebih terjamin dari segi kesyariahannya. Selama ini, dana haji yang ditempatkan di 21 Bank bisa diasumsikan tidak semuanya bank-bank tersebut adalah bank syariah. Sehingga dengan ditempatkannya dana haji pada sukuk tentu tidak akan menghawatirkan karena sejak awal sudah ada akad yang jelas.

3. Merupakan tempat investasi yang bebas default risk (gagal bayar)

Dilihat dari sisi Kementrian Agama sebagai investor, dengan menempatkan dana haji pada sukuk dana haji indonesia merupakan keputusan yang tepat. Karena hal pertama yang akan dipertimbangkan oleh investor saat akan menempatkan dananya adalah default risk, karena sukuk ini milik pemerintah maka default risk nya tida ada. Karena seluruh dana dijamin oleh pemerintah.

Dari sisi Kementrian Keuangan tentu juga mendatangkan manfaat, diantaranya yaitu:

1. Sumber pendanaan baru

Dengan ditempatkannya dana haji pada sukuk dana haji indonesia menjadi sumber pembiayaan baru bagi pemerintah untuk membiayai APBN

2. Efisiensi sektor keuangan

Dengan menempatkan dana haji langsung pada sukuk tentu akan lebih efisien karena dana langsung masuk ke kas negara dan pengelolaannya diatur langsung oleh perbendaharaan negara. berbeda ketika dana ditempatkan di sektor perbankan baru kemudian ditempatkan di surat berharga negara, hal tersebut akan menimbulkan tambahan spread karena ada tambahan efisiensi.

3. Tambahan investor

Dengan ditempatkannya dana haji pada sukuk dana haji indonesia tentunya telah menambah basis investor baru bagi kementrian keuangan. Dengan bertambahnya investor maka akan menambah masukan bagi pembiayaan pemerintah.

Adapun beberapa kekurangan pada Sukuk Dana Haji Indonesia adalah:

1. Mengurangi Jumlah Dana Pihak Ketiga Bank Syariah

19 Afzalur Rahman, Doktrin Ekonomi Islam jilid 4 (Yogyakarta: PT Dana Bhakti Wakaf, 2003), h. 506. 
Pada aplikasinya, sukuk haji ternyata menarik dana haji yang terkumpul dalam dana pihak ketiga (DPK) Bank syariah, dana yang selama ini mampu diserap dan membesarkan DPK bank syariah. Dana haji tersebut sedikit banyak telah pula mampu meningkatkan kapasitas produksi bank syariah. ${ }^{20}$

Dana triliunan itu ditarik, baik dari bank syariah maupun bank konvensional, untuk diletakkan dalam portfolio sukuk haji. Bagi bank konvensional yang telah memiliki DPK cukup besar penarikan ini relatif tidak mengganggu, tetapi dengan size bank syariah yang masih kecil, kebijakan Kementerian Agama ini tentu akan mengganggu perkembangan bank-bank syariah.

2. Keraguan pada pengelolaannya

Dari segi pengelolaannya di kas perbendaharaan negara ada sedikit kekhawatiran. Yaitu sukuk dana haji itu sendiri digunakan untuk general financing. ${ }^{21}$

Jadi ketika dana haji masuk ke kas negara maka akan dikelola oleh bagian perbendaharaan negara. Di bagian tersebut tidak ada klasifikasi atau pemisahan dana haji diagaunakan untuk apa. Tetapi dijadikan satu dengan dana-dana lain untuk kemudian digunakan untuk general financing tersebut. Secara syariah, hal tersebut menimbulkan keragu-raguan akan bercampurnya dana tersebut dengan dana non sukuk.

\section{Kesimpulan}

Dalam pengelolaan anggaran negara, sukuk merupakan salah satu instrumen pembiayaan negara. Digunakan sebagai salah satu sumber pembiayaan APBN. Dana yang berasal dari sukuk digunakan untuk pengelolaan kas, pembiayaan defisit dan pembiayaan kegiatan. Dana SDHI sendiri digunakan untuk pembiayaan secara umum (general financing), bukan untuk membiayai proyek (project financing). Maka dari itu bisa disimpulkan bahwa pengelolaan dana haji pada Sukuk Dana Haji Indonesia adalah untuk pembiayaan defisit anggaran mengingat penggunaannya adalah tergolong untuk pembiayaan secara umum. Bukan untuk membiayai proyek tertentu.

Dalam Pengelolaan APBN, realisasi penerbitan Sukuk Dana Haji Indonesia hingga tahun 2019 adalah sebesar 10,7 triliun. Dan total seri

20 Ali Sakti. Kanibalisme Kenangan Syariah, diakses pada 23 Oktober 2019 dari http://abiaqsa.blogspot.com/

21 Agus P. Laksono, Staff Direktorat Pembiayaan Syariah-Direktorat Jenderal Pengelolaan Utang Kementrian Keuangan RI, Wawancara Pribadi, Jakarta, 18 Oktober 2019 
Sukuk Dana Haji Indonesia yang sudah diterbitkan ada tujuh, yaitu SDHI 2017 A, SDHI 2017 B, SDHI 2017 C, SDHI 2018 A, SDHI 2018 A, SDHI 2018 B, SDHI 2018 C. Dari total tersebut, ada tiga yang sudah jatuh tempo, yaitu SDHI 2019 A, SDHI 2019 B, SDHI 2019 C.

Adapun kelebihan dan kekurangan pengelolaan dana haji pada Sukuk Dana Haji adalah sebagai berikut:

Kelebihan: 1) Dilihat dari sisi Kementrian Agama: Menghindari sistem risk perbankan, Lebih terjamin dari sisi kesyariahannya, Merupakan tempat investasi yang bebas default (gagal bayar). 2) Dilihat dari sisi Kementrian Keuangan: Sumber pendanaan baru, Efisiensi sektor keuangan, Tambahan investor

Kekurangan: Sukuk Dana Haji Indonesia menimbulkan dampak negatif dari sisi sektor keuangan, yaitu: Mengurangi Dana Pihak Ketiga (DPK) pada bank syariah, dan Menimbulkan keragu-raguan dari segi pengelolaannya, mengingat Sukuk Dana Haji Indonesia tersebut ditempatkan untuk general financing jadi terdapat kekhawatiran tercampur dengan dana selain sukuk.

\section{DAFTAR PUSTAKA}

Bagus, Dimas W.K., Telaah Kritis Budaya Berhutang Indonesia, diakses pada tanggal $23 \quad$ November $2019 \quad$ Dari http://suarapembaca.detik.com/read/2010/07/07/181558/1395 $\underline{067 / 471 / \text { telaah-kritis-budaya-berhutang-indonesia. }}$

Buku Perkembangan Utang Negara, Direktorat Jenderal Pengelolaan Utang-Kementerian Keuangan, edisi Oktober 2019.

Direktorat Pembiayaan Syariah-Direktorat Pengelolaan Utang Kementrian Keuangan, Mengenal Sukuk Instrumen Investasi Berbasis Syariah, diakses pada tanggal 23 September 2019 dari http://www.dmo.or.id

Firdaus, Muhammad NH,dkk., Briefcase book edukasi Profesional Syariah Sistem Keuangan dan Investasi, Jakarta: Renaisan, 2005.

Hamid, Abdul, Pasar Modal Syariah, Jakarta: Lembaga Penelitian UIN, 2009.

http://www.depkeu.go.id.htm, diakses pada tanggal 1 Februari 2019

http:/ / www.iei.or.id/publicationfiles/Manajemen $\% 20 \mathrm{Utang} \% 20$ Pemerin tah $\% 20 \% 20$ Best $\% 20$ Practices $\% 20$ dan $\% 20$ Pengalaman $\% 20$ Indon esia.pdf pada tanggal 23 September 2019

Kane, Bodie, dkk., Invesments (Investasi), Jakarta: Salemba 4, 2006.

Kritik Ekonomi Islam terhadap APBN, Majalah Sharing edisi 35 tahun IV November 2009.

Karim, Adiwarman A., Ekonomi Makro Islami, Jakarta: PT RajaGrafindo 
Persada, 2007.

Laksono, Agus P., Sukuk Negara (SBSN) Instrumen Pembiayaan dan Investasi berbasis Syariah, disampaikan pada materi Sukuk Goes to Campus, Jakarta 7 Mei 2019.

Laksono, Agus P., Staff Direktorat Pembiayaan Syariah-Direktorat Jenderal Pengelolaan Utang Kementrian Keuangan, Wawancara Pribadi, Jakarta, 18 Oktober 2019

Lampiran Keputusan Menteri Keuangan Nomor 447/KMK.06/2005 Tentang Strategi Pengelolaan Utang Negara Tahun 2005-2009, diakses pada tanggal 26 Oktober 2019 dari http://www.dmo.or.id Laporan Pertanggungjawaban Pengelolaan Surat Berharga Negara tahun 2009.

M. Umer Chapra, Sisitem Moneter Islam, Jakarta: Gema Insani Press, 2003.

Manan, Abdul, Obligasi Syariah, diakses pada tanggal 9 Juli 2019 dari http://www.badilag.net

Moeljadi, Manajemen Keuangan Pendekatan Kuantitatif dan Kualitataif jilid 1, Jawa Timur: Bayumedia Publishing, 2006.

Mustafa Edwin Nasution, Kritik Ekonomi Islam terhadap APBN, Majalah Shariang edisi 35 tahun IV November 2009.

Nurul Huda dan Mustafa E. Nasution, Investasi pada Pasar Modal Syariah,Jakarta: Kencana, 2008.

Pembiayaan Defisit Anggaran, Pengelolaan Utang, dan Risiko Fiskal, diakses pada tanggal 23 Oktober 2019 dari http:/ / docs.google.com/viewer?url=http://www.anggaran.depke u.go.id/Content/08-08-15,+B+VI.pdf\&chrome=true.

Penempatan Dana Haji dan Dana Abadi Umat ke SBSN lebih aman, diakses pada tanggal 28 januari 2019 dari http://www.jurnalhaji.com.htm

Rahman, Afzalur, Doktrin Ekonomi Islam jilid 4, Yogyakarta: PT Dana Bhakti Wakaf, 2003.

Rochaety, Etty, dkk., Metode Penelitian Bisnis, Jakarta: Mitra Wacana Media, 2007.

Rodoni, Ahmad, Investasi Syariah, Jakarta: Lembaga Penelitian UIN, 2009.

Sakti, Ali, Kanibalisme Keuangan Syariah, diakses dari http:/ / abiaqsa.blogspot.com/ pada tanggal 23 November 2019

Sambutan Menteri Keuangan pada Acara Penandatanganan MoU antara Menteri Keuangan dan Menteri Agama dalam rangka Penempatan Dana Haji dan DAU dalam SBSN, diakses pada tanggal 1 Februari 2019 dari http//www.depkeu.go.id.htm.

Suad Husnan, Dasar-dasar Teori Portofolio dan Analisis Sekuritas, Yogyakarta: UPP AMP YKPN, 2005.

Sudarsono, Heru, Bank dan Lembaga Keuangan Syariah, Yogyakarta: 


\section{Ekonosia-FH UII, 2007.}

Sukuk Dana Haji Kembali Terbit, diakses pada tanggal 23 November 2019 dari http://bataviase.co.id/node/215191

Sumadi Suryabrata, Metodologi Penelitian, Jakarta: Rajawali Press, 2002.

Suprayitno, Eko, Ekonomi Islam Pendekatan Ekonomi Makro Islam dan Konvensional, Yogyakarta: Graha Ilmu, 2005.

Trie, Arief Hardiyanto, Pengelolaan Utang Negara Analisis Risiko dan Strategi Utang, diakses pada tanggal 23 September 2019 dari http://www.pusdiklatwas.bpkp.go.id/artikel/namafile/34/paper_ S3-hutang-v.doc.

Kalsum, Umi dan Agus Dwi Darmawan, Depag Siap Tarik Dana Haji di 21 Bank, diakses pada tanggal 1 Februari 2019 dari http://www.bisnis.vivanews.com 2.htm. 